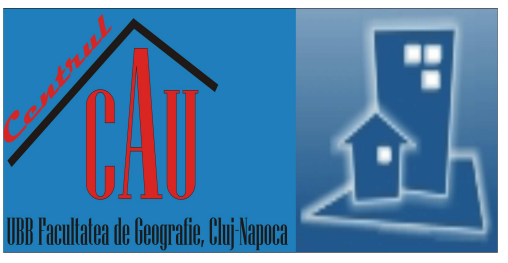

\title{
Guest Editorial \\ Territorial Identities and Sustainable Development. Challenges and Solutions
}

\author{
Marinela ISTRATE 1 , Oana-Ramona ILOVAN ${ }^{{ }^{2}}$ \\ * Corresponding author \\ 1 "Al. I. Cuza" University of Iaşi, Faculty of Geography and Geology, Department of Geography, Iaşi, ROMANIA \\ 2 Babeș-Bolyai University, Faculty of Geography, Department of Regional Geography and Territorial Planning, Territorial Identities \\ and Development Research Centre, Cluj-Napoca, ROMANIA \\ $\triangle$ istrate.marinela@uaic.ro (D) https://orcid.org/oooo-0oo2-1456-6772 \\ $\triangle$ oana.ilovan@ubbcluj.ro (iD https://orcid.org/oooo-0oo3-2075-1808
}

DOI: 10.24193/JSSPSI.2021.8.01

https://doi.org/10.24193/JSSPSI.2021.8.01

K e y w o r d s: community development, public policy, smart and green communities, urban and rural regeneration

\begin{abstract}
A B S T RA C T
Territorial belonging and territorial attractiveness are elements of strategic relevance for development at various levels. Therefore, territorial identity is relevant for building the social capital so useful during the processes of development and territorial planning. The concern about territorial identity and development is part of the same trend that occurred in the academic and political environment after the 1990s, when it became obvious that there was a strong connection between these and environmental, social and economic well-being. This special issue hosts the results of original empirical and theoretical scientific research on territorial identity and its relation to sustainable development.
\end{abstract}

This special issue proposes a discussion about territorial identity from the perspective of sustainable development. Without discussing in detail the relationship between the two concepts, we want to illustrate the relationship between the different dimensions of territorial identity that are part of the general picture of sustainability and reflect the degree of territorial insertion of new approaches to development, less intrusive and friendlier with the environment and with the human society.

Qualitative and quantitative analyses allow for some reflection on the general context and the more or less sustainable future of development. The notion of territorial identity has a multitude of meanings, ranging from simple terms such as "uniqueness", "singularity", "authenticity" and going to "traditional versus modern", "accessible versus isolated", etc. (Roca and Roca, 2007). In the context of increasingly frequent correlations between economic progress, limited natural resources and environmental issues (Istrate, Horea-Şerban and Bănică, 2019), territorial identity has become a hot topic for both researchers and decision-makers, being considered a driver of long-term stable economic development, able to reconcile economic growth and sustainable development at local and regional level (Banini, 2017, 2021; Banini and Ilovan, 2021; Haartsen, Groote and Huigen, 2000).

The assertion and capitalisation of territorial identity will be the key factors for increasing the efficiency of using local and regional potential in the 
coming years, so the focus of current European policies is on the need to preserve local / regional identity while implementing development strategies leading to economic, smart, inclusive, and sustainable growth. The capitalisation of the local cultural identity is starting to become a useful tool in creating new job-generating activities and an element of attractiveness for both locals and potential investors.

Sustainable development presupposes, as a necessary (but not sufficient) condition, the maintenance of a balance between the three basic components that form the territorial identity (Roca and Mourão, 2004): socio-cultural elements (rural heritage, urban historic centres, tourism, local cultures, public spaces), the socio-economic elements (creation of new jobs, education, entrepreneurial spirit, presence of secondary residences, aged population, rural-urban inequality, social crises and conflicts), as well as the technical-economic ones (new communication and information technologies, organic farming, traditional agriculture, water pollution). The problem is to determine which characteristics of territorial identity must be consolidated, diversified, developed or, conversely, preserved, so as to become pillars of sustainable development, in relation to the objectives of local or regional proposals (Roca and Roca, 2007).

Finally, we can mention that "the concept of territorial identity can be regarded, then, as the collective recognition of an intricate meshing of characteristics and components specific to a given social fabric, unique to the inhabitants of a spatial unit and determined by its particular resources and the environmental, political institutional, economic and sociocultural dimensions" (Luiz de Miranda and Adib, 2007, p. 43).

The articles included in this special issue aim at drawing the relationship between territorial identity and sustainable development following two distinct directions: on the one hand, the problems generated by the recent expansion of rural and urban settlements (territorial identity and secondary housing in rural areas, peri-urban expansion and alteration of the territorial identity), and on the other hand, are targeted a series of economic activities that can influence the identity of the place (lignite extraction, organic farming, adaptation of tourism to new societal requirements, emergence and functioning of bioregions).

Two articles focus on the recent development of human settlements, highlighting the spatial and social implications of this phenomenon. The first of these is written by Ioana Alexandra Ciupe, who discusses the expansion of secondary housing in the Apuseni Nature Park area, which contributes to the fundamental change of the environment and the contemporary rural landscape, not always with positive effects. Determining the spatial models of secondary housing location according to the characteristics of the local environment (land cover, altitude, climate, management system for protected areas) and other social aspects (tourism, old settlements), using the Principal Components Analysis (PCA), led to identification of no less than nineteen types of rural landscapes. The author's approach can come to the aid of local decision makers, those who would train to develop an integrated and sustainable spatial planning (Ciupe, 2021).

In the second article, Oliver-Valentin Dinter and Lucian Roșu analyse the problems generated by the uncontrolled, rapid and chaotic development of the peri-urban areas of large cities, carrying out a case study on Iaşi/Jassy, a big city in the eastern part of Romania. Urban sprawl, often seen as indicating economic growth and a possible response to the housing crisis in large cities (Roșu, Istrate and Bănică, 2018), can become a source of conflict generated by falling prices for existing housing by inserting new collective or individual housing complexes. The aspects mentioned above were analysed by the authors by calculating an index of conflict triggers. The results suggest that, although theoretically, through proper urban planning, the expansion of suburbs can generate a sense of belonging to the community, improving territorial identity and social cohesion, in the case of Iaşi/Jassy, lack of planning and adequate infrastructure increase segregation and conflicts within the community (Dinter and Roșu, 2021).

As author Kinga Xénia Havadi-Nagy points out in her article, rural development policies and strategies should also include issues related to the ecological, cultural and social services that farms can currently provide. One of the successful initiatives that tend to expand more and more in Romania is represented by alternative food networks, an expression of recognising the benefits that small-scale, less intensive and more diversified agriculture brings. Although alternative food networks are promoted through websites and social networking platforms, institutional and political support is needed to enable them to become a sustainable and effective tool for rural development (Havadi-Nagy, 2021).

An interesting correlation between two very current concepts, the aging population and the ability of the hospitality industry to adapt, innovate and respond to the new demographic challenges of the society is made by Ana-Maria Taloş et al. The aging of the population, by prolonging the life period and continuously gathering numerous old age generations, can be considered one of the most profound social changes today because it is the result of many processes that manifest over a longer period. Unlike Western European countries that had become prosperous before the clear manifestation of population aging trends, Romania runs the risk of having an aging population demographically without truly experiencing large-scale 
economic prosperity. However, concepts such as silver economy policies and active aging are becoming more widespread, in light of the newly designed EU policies. Even if the difference in income and education level influences preferences and sets limitations in terms of recreational activities and leisure tourism among the elderly, well-personalised and tailored vacation packages would help strengthen an active old age, with all the benefits that flow from it (Taloş et al., 2021).

Local identity and attachment to the places can be disrupted by the implementation of economic activities, especially when it comes to open-cast lignite mining. Iwona Markuszewska's article shows that fossil fuels are not only the most important industrial sources of air pollution in the European Union, but also that their exploitation can influence the life of local communities, when they interfere with agricultural areas and the proper conduct of traditional activities (Markuszewska, 2021).

The article that closes this special issue discusses the role of information and communication technology (ICT) in the creation of bioregions. The authors, Adrian-Daniel Muntean, Remus-Adrian Caranfil and Oana-Ramona Ilovan, show that the demand for organic/eco food of cities, as well as fertile soil, created the premise for starting many eco/biocertified farms and enterprises, even if in Romania there is inequality at the regional level in terms of the number of sustainable practices. Thus, the authors note that the eastern regions are less involved in the development of bioregions, while the west of the country and especially areas near important urban centres are favoured, and a higher concentration of population is not correlated with a higher number of sustainable practices in this field (Muntean, Caranfil and Ilovan 2021).

To conclude, the territorial approach is a strategic dimension of the process of planning and implementation of public policies under conditions in which "as a strategy for public policies, typologies based on territorial identity make it possible, based on the convergence of interests of the social actors and public agents, to objectively orient sustainable rural development actions in a given space" (Luiz de Miranda and Adib, 2007, p. 43).

We hope that each of the articles included in this special issue represents a step forward in highlighting the many facets of the link between the concepts of territorial identity and sustainable development and in emphasising the importance of reconstituting local identity in all its dimensions.

\section{ACKNOWLEDGEMENTS}

We thank Vasile Zotic and Diana-Elena Alexandru, from the editorial team of Journal of
Settlements and Spatial Planning, for their support to convey this issue. Moreover, we are grateful to all our colleagues from Romania and abroad who reviewed submissions.

\section{REFERENCES}

Banini T. (2017), Proposing a theoretical framework for local territorial identities: concepts, questions and pitfalls. Territorial Identity and Development, 2(2), 16-23

Banini T. (2021), Chapter 1. Towards a methodology for constructing local territorial identities. In: Ilovan O.-R. (ed.), Territorial Identities in Action. Presa Universitară Clujeană, Cluj-Napoca, 13-39

Banini T., Ilovan O.-R. (2021), Introduction: dealing with territorial/place identity representations. In: Banini T., Ilovan O.-R. (eds.), Representing Place and Territorial Identities in Europe. GeoJournal Library, vol. 127. Springer, Cham, 1-19. https://doi.org/10.1007/978-3-030-66766-5_1

Ciupe I.-A. (2021), Spatial patterns of second home development as part of rural landscapes. A case study of Apuseni Nature Park. Journal of Settlements and Spatial Planning, Special Issue 8, 65-77, DOI: 10.24193/JSSPSI.2021.8.06

Dinter O.-V., Roşu L. (2021), Evaluating the potential conflicts of collective housing development in the suburbs of Iaşi, Romania. Journal of Settlements and Spatial Planning, Special Issue 8, 49-63, DOI: 10.24193/JSSPSI.2021.8.05

Haartsen T., Groote P., Huigen P. P. (2000), Claiming Rural Identities. Van Gorcum, Assen. ISBN 90 23235673 OA 37.50

Havadi-Nagy K.-X. (2021), Alternative food networks in Romania - Effective instrument for rural development? Journal of Settlements and Spatial Planning, Special Issue 8, 15-27, DOI: 10.24193/JSSPSI.2021.8.03

Istrate M., Horea-Şerban R., Bănică A. (2019), Progress in eco-innovation for green and resilient development in European Union with a focus on Central and Eastern European countries. Journal of Environmental Protection and Ecology, 4, 1814-1821

Luiz de Miranda C., Adib A. R. (2007), Sustainable development and the territorial approach: identities and typologies. Comuniica Magazine, Inter-American Institute for Cooperation on Agriculture, vol. 2007(05o8 May), 1-8, DOI: 10.22004/ag.econ.188580

Markuszewska I. (2021), 'Old trees cannot be replanted': when energy investment meets farmers' resistance. Journal of Settlements and Spatial Planning, Special Issue 8, 5-13, DOI: 10.24193/JSSPSI.2021.8.02 Muntean A.-D., Caranfil R.-A., Ilovan O.-R. (2021), Urban bioregions and territorial identities in Romania. The role of information and communication technology. Journal of Settlements and Spatial 
Planning, Special Issue 8, 78-93. DOI: 10.24193/JSSPSI.2021.8.07

Roca Z., Roca M. N. O. (2007), Affirmation of territorial identity: A development policy issue. Land Use Policy, 24, 434-442, doi:10.1016/j.landusepol.2006.05.007

Roca Z., Mourão J. C. (2004), Territorial identity and sustainable development: from concept to analysis. Campus Social: Revista Lusófona de Ciências Sociais, 1, 85-103
Roşu L., Istrate M., Bănică A. (2018), Passenger car dependency and consequent air pollutants emissions in Iași Metropolitan Area (Romania). Environmental Engineering and Management Journal (EEMJ), 17, 4, 865-875

Taloş A.-M., Lequeux-Dincă A.-I., Preda M., Surugiu C., Mareci A., Vijulie I. (2021), Silver tourism and recreational activities as possible factors to support active ageing and the resilience of the tourism sector. Journal of Settlements and Spatial Planning, Special Issue 8, 29-48, DOI: 10.24193/JSSPSI.2021.8.04 